related particle (PREPs) to the packaging procedure. Hum. Gene Ther. (In press).

19.Wang, S., S. Di, W.B. Young, C. Jacobson and C.J. Link. 1997. A novel herpesvirus amplicon system for in vivo gene delivery. Gene Ther. 4:1132-1141.

20.Wang, Y., L. Yu and A.I. Geller. Diverse stabilities of expression in the rat brain from different cellular promoters in a helper virus-free HSV-1 vector system. Hum. Gene Ther. (In press).

We gratefully acknowledge $\mathrm{Dr} . W$. Schlaepfer for the NFH promoter, Dr. R. Sandri-Goldin for 2-2 cells and Dr. A. Davison for the HSV-1 cosmids. Supported by Neurovir and NS34025 (A.G.). Address correspondence to Alfred Geller, Division of Endocrinology, Children's Hospital, Boston, MA 02115, USA. Internet: geller_a@ al.tch.harvard.edu

Received 26 May 1999; accepted 5 August 1999.

X. Wang, G.-r. Zhang, T. Yang, W. Zhang and A.I. Geller Children's Hospital

Boston, MA, USA

\section{High-Throughput Method for Isolating Plasmid DNA with Reduced Lipopoly- saccharide Content}

BioTechniques 28:106-108 (January 2000)
DNA with significantly less lipopolysaccharides (LPS), which is otherwise a common bacterial contaminant of silica oxide-isolated DNA and inhibits subsequent applications. In addition, we have implemented a precipitation step that altogether leads to a reduction of the LPS content by a factor of 900 relative to published methods. Our novel protocol facilitates an inexpensive highthroughput analysis of pure plasmids in a 96-well format without the addition of hazardous reagents.

\section{INTRODUCTION}

Purifying plasmid DNA from bacteria is a commonly used procedure that is the basis for cloning, sequencing, functional expression screens and newer applications like gene therapy. Each of these manipulations requires the isolation of plasmid DNA at high purity. Commercial anion exchange columns, even though they are expensive, are widely used for this purpose. Less expensive methods, such as the use of silica oxide, have the disadvantage that bacterial lipopolysaccarides (LPS or endotoxins) are copurified, which can interfere with downstream applications $(2,6,7)$. Furthermore, silica oxide requires the use of chemicals, such as guanidine hydrochloride, that act as chaotropic substances by changing the structure of water and facilitate the binding of DNA to silica oxide (3). Because many of these applications require iterative plasmid isolations, we wanted to develop a protocol for a plasmid preparation in a 96-well format based on silica oxide as an established and inexpensive DNA binding matrix. At the same time, we sought to obviate the disadvantages of DNA isolation by silica oxide. Here, we describe the implementation of such an experimental protocol.

\section{MATERIALS AND METHODS}

\section{Preparation of Silica Oxide}

Silica oxide (Sigma, Deisenhofen, Germany) was dissolved in $250 \mathrm{~mL}$ water as a $50 \mathrm{mg} / \mathrm{mL}$ suspension. After incubation for $30 \mathrm{~min}$, the fines were removed by suction, and the volume was reconstituted. The solution was 
treated by adding $150 \mu \mathrm{L} \mathrm{HCl} \mathrm{(37 \% )}$ and was autoclaved.

\section{Determination of LPS Content}

We used a commercially available colorimetric test (BioWhittaker, Walkersville, MD, USA), to determine the LPS level. According to the manufacturer, the detection limit of this assay is $0.1 \mathrm{EU} / \mathrm{mL}$ endotoxin. We used internal controls to calibrate the tests.

\section{Plasmid DNA Isolation in 96-Well Plates}

A 96-well block containing $900 \mu \mathrm{L}$ of LB medium with bacteria of an overnight culture in each well was centrifuged for $5 \mathrm{~min}$ at $3000 \times \mathrm{g}$ (Sigma Zentrifugen, Osterode am Harz, Germany). The supernatant was decanted, the block was inverted on Kimwipes ${ }^{\circledR}$ for 2-3 min and $170 \mu \mathrm{L} \mathrm{F1}$ buffer (50 $\mathrm{mM}$ Tris-HCl/10 mM EDTA, $\mathrm{pH}$ 8.0) were added. The bacteria pellets were completely resuspended by vortex mixing for 10-20 min Then, $170 \mu \mathrm{L} \mathrm{F2}$ buffer $(200 \mathrm{mmol} / \mathrm{L} \mathrm{NaOH}, 1 \%$ SDS $)$ were added, the block was sealed with tape (ScotchPad, 3M, Neuss, Germany), inverted and incubated at room temperature for $5 \mathrm{~min}$. However, the $170 \mu \mathrm{L}$ of $4^{\circ} \mathrm{C}$ cold buffer $\mathrm{F} 3(3 \mathrm{~mol} / \mathrm{L}$ KOAc, $\mathrm{pH}$ 5.5) terminated the lysis. The 96-well block was then sealed with tape and inverted to mix the solutions. Ten microliters of an RNaseA solution $(1.7 \mathrm{mg} / \mathrm{mL})$ were added to digest excessive RNAs, incubated for $5 \mathrm{~min}$ at room temperature and then at $-20^{\circ} \mathrm{C}$ for $10 \mathrm{~min}$ to efficiently precipitate proteins and genomic DNA.

The solution was again centrifuged for $10 \mathrm{~min}$ at $5800 \times g$. The supernatant was decanted in new blocks, and the samples received $100 \mu \mathrm{L}$ buffer F4 (2.5\% SDS in isopropanol) to precipitate LPS. The block was vortex mixed for $5 \mathrm{~min}$ and incubated, first at $4^{\circ} \mathrm{C}$ for $15 \mathrm{~min}$ and then at $-20^{\circ} \mathrm{C}$ for $15 \mathrm{~min}$. The block was again centrifuged for 10 $\min$ at $5800 \times g$, and the supernatant was added to robust, custom-made 96well polyoxymethylene microtiter blocks. One-hundred and fifty microliters of silica oxide suspension were added and incubated for $20 \mathrm{~min}$ at room temperature. The plates were cen- trifuged for $5 \mathrm{~min}$ at $5800 \times \mathrm{g}$, the supernatant was carefully decanted and $400 \mu \mathrm{L}$ wash solution (acetone or $75 \%$ isopropanol, $-20^{\circ} \mathrm{C}$ ) were added. The plates were again vortex mixed for $30 \mathrm{~s}$ and centrifuged for $3 \mathrm{~min}$ at $5800 \times \mathrm{g}$. The wash step was repeated once. The pellets were first dried at room temperature for $5 \mathrm{~min}$ and then for $5 \mathrm{~min}$ in a vacuum chamber. They were subsequently resuspended in $75 \mu \mathrm{L}$ LPS-free water at $60^{\circ} \mathrm{C}$ by vortex mixing for $30 \mathrm{~s}$ and centrifuged at maximum speed at $5800 \times g$ for $10 \mathrm{~min}$ at $4^{\circ} \mathrm{C}$ to pellet the silica oxide. The supernatant contained the isolated plasmid DNA.

For DNA midipreps (100 mL bacteria culture) $240 \mathrm{mg}$ silica oxide were used; for maxipreps (from $500 \mathrm{~mL}$ bacteria culture) $2.25 \mathrm{~g}$ silica oxide were applied to the lysate.

\section{Transfection of Cells}

The human embryonic cell line 293 was transfected as described (4) with calcium phosphate co-precipitation whose efficiency is sensitive to LPS. Transfection efficiencies were assayed with the plasmid pGreenLantern ${ }^{\mathrm{TM}}$ (Life Technologies, Gaithersburg, MD, USA), which encoded the green fluorescent protein (1).

\section{RESULTS AND DISCUSSION}

Silica oxide is known to interact with DNA in the presence of chaotropic substances (5). However, we unexpectedly discovered that, even without an added chaotropic reagent such as guanidine hydrochloride, there was no decline in the DNA binding capacity of silica oxide (Table 1). We stepwise reduced the concentration of guanidine hydrochloride, but even when we excluded this chemical altogether, we did not observe a significant drop in the yield of plasmid DNA (Table 1). We also found that chaotropic substances are not required for DNA binding to other silica-based DNA adsorption matrixes such as commercially available spin columns (data not shown). The DNA binding is dependent on the presence of silica oxide and potassium acetate in the reaction (data not shown). Possibly, the high potassium acetate
Table 1. DNA Binding to Silica Oxide in the Presence of Different Concentrations of a Chaotropic Reagent

\begin{tabular}{|c|c|}
\hline $\begin{array}{l}\text { Guanidine } \\
\text { Hydrochloride } \\
\text { (M) }\end{array}$ & $\begin{array}{l}\text { Plasmid DNA } \\
\qquad(\mu \mathrm{g} / \mathrm{mL})\end{array}$ \\
\hline 0 & $134.1 \pm 46.9$ \\
\hline 0.5 & $135.3 \pm 28.8$ \\
\hline 1 & $192.3 \pm 48.3$ \\
\hline 1.5 & $161.3 \pm 61.1$ \\
\hline 2 & $157.5 \pm 23.5$ \\
\hline \multicolumn{2}{|c|}{$\begin{array}{l}\text { Plasmid DNA (pGreen Lantern) was } \\
\text { isolated from } 1 \mathrm{~mL} \text { of LB medium af- } \\
\text { ter an alkaline lysis of bacteria } \\
\text { ( } E \text {. coli SURE }{ }^{\circledR} \text {; Stratagene, La Jolla, } \\
\text { CA, USA). Different concentrations } \\
\text { of the chaotropic substance guani- } \\
\text { dine hydrochloride were added as } \\
\text { indicated, and the amount of DNA } \\
\text { that could bind to } 7.5 \text { mg silica oxide } \\
\text { was determined photometrically } \\
\left(A_{260}\right) \text {. Given are the means and } \\
\text { standard deviations of three } \\
\text { independent experiments for each } \\
\text { condition. }\end{array}$} \\
\hline
\end{tabular}

concentration used to neutralize the alkaline lysis of bacteria is sufficient to facilitate the DNA binding to silica. The omission of a hazardous reagent such as guanidine hydrochloride is a major safety advantage of our protocol.

One of the most frequent contaminants of silica oxide-isolated DNA are lipopolysaccharides that are abundant in the membrane of bacteria and lead to significant reductions in transfection efficiency and toxic side effects in gene therapy $(6,7)$. However, we observed that the exclusion of a chaotropic substance results in an LPS content of less than $50 \mathrm{U} / \mu \mathrm{g}$ DNA (Table 2 ) in contrast to more than $1000 \mathrm{U} / \mu \mathrm{g}$ with conventional silica oxide isolations (6). We also tested several washing conditions and found that a washing step with acetone removes LPS much more efficiently than the widely used isopropanol.

Furthermore, the absence of a chaotropic substance in our protocol allowed us to use additional reagents to purify the DNA, which would other- 
Table 2. LPS Levels in 96-Well Plasmid Isolations after Acetone Wash and SDS Precipitation

\begin{tabular}{|c|c|}
\hline Treatment & 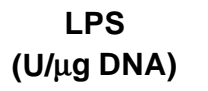 \\
\hline Isoprop. Wash & $26.5 \pm 6.3$ \\
\hline $\begin{array}{l}\text { Isoprop. Wash } \\
\quad+\text { SDS }\end{array}$ & $3.2 \pm 0.6$ \\
\hline Acetone Wash & $7.9 \pm 4.4$ \\
\hline $\begin{array}{l}\text { Acetone Wash } \\
\quad+\text { SDS }\end{array}$ & $1.3 \pm 0.4$ \\
\hline \multicolumn{2}{|c|}{$\begin{array}{l}\text { Half of the } 96 \text {-well plate was washed } \\
\text { with acetone, the other half with } 75 \% \\
\text { isopropanol. Half of each wash con- } \\
\text { dition was additionally treated with } \\
\text { SDS solution ( } 2.5 \% \text { in isopropanol). } \\
\text { The LPS levels were determined and } \\
\text { the means and standard deviations } \\
\text { of three different wells from a } 96 \text {-well } \\
\text { plate for each condition are shown. }\end{array}$} \\
\hline
\end{tabular}

wise interfere with DNA binding. We introduced a simple precipitation step to further reduce the LPS concentration. To this end, we exploited the fact that LPS has an amphipathic character. Using SDS (2.5\% in isopropanol), another amphipathic molecule that can be removed easily by coprecipitation in alcohol, we obtained a reduction in the LPS activity of the DNA isolations by a factor of eight relative to the acetonewashed control samples.

Combining the purification effects of the exclusion of guanidine hydrochloride, acetone wash and SDS precipitation, we achieved a reduction of the LPS content by a factor of 900 in comparison with published silica-based plasmid purifications (Reference 6 and Table 2). The level of LPS in our DNA isolations is comparable to CsCl- or anion exchange-purified plasmid DNA (6). In accordance, we have observed equal transfection efficiencies between our small scale DNA isolations and DNA purified by anion exchange columns (data not shown). With this protocol, we routinely obtain approximately $10 \mu \mathrm{g}$ of a high copy number plasmid from $900 \mu \mathrm{L} \mathrm{LB}$ medium with an $\mathrm{A}_{260 / 280}$ of 1.8 or better, $80 \%$ of which is in the supercoiled form (data not shown). In addition to its use for a high-throughput format, this protocol could easily be upscaled for midi and maxi DNA preparations (data not shown). Therefore, it has the potential to considerably widen the application of silica oxide for the isolation of pure plasmid DNA.

\section{REFERENCES}

1.Chalfie, M., Y. Tu, G. Euskirchen, W.W. Ward and D.C. Prasher. 1994. Green fluorescent protein as a marker for gene expression. Science 263:802-805.

2.Cotten, M., A. Baker, M. Saltik, E. Wagner and M. Buschle. 1994. Lipopolysaccharide is a frequent contaminant of plasmid DNA preparations and can be toxic to primary human cells in the presence of adenovirus. Gene Ther. 1:239-246.

3.Hansen, N. J., P. Kristensen, J. Lykke, K.K. Mortensen and B.F. Clark. 1995. A fast, economical and efficient method for DNA purification by use of a homemade bead column. Biochem. Mol. Biol. Int. 35:461-465.

4.Roussel, M.F., C.W. Rettenmier, A.T. Look and C.J. Sherr. 1984. Cell surface expression of v-fms-coded glycoproteins is required for transformation. Mol. Cell Biol. 4:1999-2009.

5.Vogelstein, B. and D. Gillespie. 1979. Preparative and analytical purification of DNA from agarose. Proc. Natl. Acad. Sci. USA 76:615619.

6.Weber, M., K. Moller, M. Welzeck and J. Schorr. 1995. Effects of lipopolysaccharide on transfection efficiency in eukaryotic cells. BioTechniques 19:930-940.

7.Wicks, I.P., M.L. Howell, T. Hancock, H. Kohsaka, T. Olee and D.A. Carson. 1995. Bacterial lipopolysaccharide copurifies with plasmid DNA: implications for animal models and human gene therapy. Hum. Gene Ther. 6:317-323.

We would like to thank Dr. M.K.A. Bauer and Alexis Schubert for suggestions concerning the manuscript and the Bavarian Government and Roche Diagnostics for their support. Address coresspondence to Dr. Stefan Grimm, Max-Planck-Institute for Biochemistry, Am Klopferspitz 18a, 82152 Martinsried, Germany. Internet: sgrimm@ biochem.mpg.de

Received 19 May 1999; accepted 12 July 1999.

Frank Neudecker and

Stefan Grimm

Max-Planck-Institute

for Biochemistry

Martinsried, Germany 